\title{
ITS IN FUNCTION OF IMPROVING ENVIRONMENTAL PARAMETERS IN THE AREA OF SARAJEVO CANTON
}

\author{
Samir Čaušević ${ }^{1}$, Jasmina Olovčić ${ }^{2}$, Kire Dimanoski ${ }^{3}$, Edo Memišević ${ }^{4}$, Adisa Memišević ${ }^{5}$ \\ ${ }^{1}$ Faculty of Traffic and Communications University of Sarajevo, Zmaja od Bosne 8, 71000 Sarajevo, \\ Bosnia and Herzegovina \\ ${ }^{2}$ PC Motorways of FB ${ }^{\prime} H$ Ltd. Mostar, Braće Fejića bb, 88000 Mostar, Bosnia and Herzegovina \\ ${ }^{3}$ Faculty of Technical Science, St. Kliment Ohridski University, Bitola, Republic of Macedonia \\ ${ }^{4}$ BIHAMK Asistencija d.o.o., Skenderija 23, 71000 Sarajevo, Bosnia and Herzegovina \\ ${ }^{5}$ Udruženje humanost $i$ inžinjerstvo "HumIng", Topal Osman Paše 55, 71000 Sarajevo, Bosnia and \\ Herzegovina
}

Received 22 September 2017; accepted 27 November 2017

\begin{abstract}
Sustainable mobility in urban road network it can barely be achieved without reducing the adverse environmental impact. Most of the cities have applied ITS systems in order to reduce air pollution especially in the center of the city. Air pollution is making worse in terms of traffic congestion, so that some of ITS solutions improve the efficiency of traffic while reducing air pollution. These specific services include: managing traffic flows, monitoring of air pollution, information on air quality, changes in management strategy approach regarding the main arteries with high levels of air pollution. In many situations, the environmental benefits can only be estimated using simulation. Today at 21 st century, the traffic engineering is seeking new methods for achieving safe, efficient and reliable transport, with minimal impact on the environment and society. The main indicator is the performance of the major requirements with lower costs as ultimate goal. Establishing Low-Emission Zone and the central traffic management system, the problem of pollution in the Canton of Sarajevo would be neutralized, quickly and efficiently.
\end{abstract}

Keywords: ITS, environment, pollution, traffic management center, low emission zone.

\section{Introduction}

The rapid development of the information technology over the last twenty years has completely changed the way of working in many fields, and so in the field of transport. The Intelligent Transport Systems can be defined as integrated application of computers, communication technologies and management strategies to increase the safety and efficiency of the transport system.
Today, urban ITS is fundamental factor of an efficient, safe and environmentally friendly urban transport system.

The Intelligent transport systems include a wide range of information, surveillance, control and electronic technologies that enable more efficient monitoring and management of traffic flows in order to increase productivity, protect people's lives and save time and money.

\footnotetext{
${ }^{2}$ Corresponding author: o.jasmina@jpautoceste.ba
} 
Transport has become a very important dimension of the concept of sustainability. The main environmental dimensions of transport are related to the causes, activities, outputs and results of the transport system (Čaušević and Bošnjak, 2011).

The occurrence and frequency of increased concentrations of pollutants in the atmosphere depends primarily on the size and distribution of emission sources, local topography, local climatic conditions (average wind speed, temperature inversion). The significance of pollution depends primarily on the type of pollutant, exposure, health and other effects associated with exposure. The most significant air pollutants are sulfur dioxide $\left(\mathrm{SO}_{2}\right)$, particulates, nitrogen oxides $\left(\mathrm{NO}_{\mathrm{x}}\right)$, carbon monoxide $(\mathrm{CO})$, ozone $\left(\mathrm{O}_{3}\right)$, lead $(\mathrm{Pb})$, other heavy metals and organic compounds resulting from various activities. The main source of air pollution in urban areas is the heating of households, industrial activity and traffic. Relevant differences in occurrence and frequency of high concentration episodes can be related to different local meteorological and topographic conditions.

The transport industry, especially road transport, is considered to be the main source of pollutants such as $\mathrm{CO}, \mathrm{NO}_{\mathrm{x}}$, VOCs, and an important source of $\mathrm{CO}_{2}$ emissions that contributes to increasing the Greenhouse effect. Regardless of the reduction in the use of lead-containing fuels, the percentage of lead in exhaust gases in a large number of countries is worrying above the permitted concentration limits.

\section{The Impact of Traffic on Environmental Pollution in the Area of Sarajevo Canton}

Due to today's mobility of people, goods and services, the increase in air pollution in Sarajevo Canton is evident, especially in certain seasons, in the late fall and winter. It is considered that the traffic is the second air pollutant, after the pollution caused by heating systems in Sarajevo Canton. The development of the traffic in such circumstances must be in line with the principles of sustainable development that have already been defined at a global, international level. Traffic is one of the areas in which the indicators of growth are analyzed through the definition of sustainable development, mostly with the negative aspect; all efforts and improvements in the reduction of emissions of harmful substances, increasing the quality of fuel, increase fuel efficiency, even the introduction of new alternative fuels, pale before the data on the significant increase in the number, power and usage of vehicles of all kinds, especially road motor vehicles. Increasing the use of personal vehicles in relation to the reduction in the use of public transport modes that are less influential on the environment is worrying.

The effect of pollutants to the environment is reflected in the global climate change at regional level phenomenon of acid rain, and the local level smog phenomenon (Šimunović et al., 2002). Pollutants are released into the air in the form of gases, vapors and dust. Exhaust gases contain over 500 organic and inorganic substances. Their composition depends on the fuel used, combustion degree and engine operating regime. They typically occur when filling up automobile tanks and fueling gas stations. The emission of harmful substances depends primarily on the size and structure of the traffic, the driving dynamics (free flow, stops), the strength of the source, the duration of the emission, age and general condition of the vehicle. 
Pollutant emissions from road transport are result of the engine combustion. The basic combustion products of fossil fuels in internal combustion engines are carbon dioxide and water vapor. But, inefficiency of the engine and high operating temperature also produce many other gases. The most important pollutants (by-products) for internal combustion engines are nitrogen oxides, hydrocarbons, carbon monoxide, sulfur dioxide, particles (soot), lead, aldehydes, and secondary pollutants formed in the atmosphere after they are released (photochemical smog). The quantity of emission of pollutants depends on various factors. For individual vehicles the emissions depend on the following factors (Lindov, 2013):

- Types and power of the engine;

- Types and composition of fuels (sulfur content in diesel fuel and lead in gasoline has a significant influence on $\mathrm{SO}_{2}$ or lead concentration);

- Engine maintenance level;

- The age of cars (the emission reduction technologies of cars are constantly improving, so there is interdependence between the car age and the emission of polluting substances);

- Motor temperature (cold engine runs at lower power consumption).

The total traffic emissions depends on the following factors (Lindov, 2013):

- Vehicle number (vehicle flow per hour or per day);
- Composition of vehicles by type and age structure (heavy vehicles with large engines emit larger quantities of pollutants than light vehicles, under the same other conditions. Diesel engines have higher emissions of $\mathrm{SO}_{2}, \mathrm{NO}_{\mathrm{X}}$ and solid particles while gasoline engines have higher $\mathrm{CO}$ and hydrocarbon emissions);

- Driving modes (average speed, uninterrupted flow or traffic jams) (most vehicles work most efficiently at speeds between 80 and $100 \mathrm{~km} / \mathrm{h}$ );

- Road characteristics (vehicles emit excessive amounts of polluting substances during slowdown or acceleration as well as overflow, so roads requiring these actions have an impact on increasing emissions of polluting substances).

The road network in the Sarajevo Canton has been organized as a Combined System of street networks (Organic System). The total length of the road in Sarajevo Canton is $1,107.44 \mathrm{~km}$ and it is defined by the Mid-term Plan and Program for Maintenance, Protection, Reconstruction and Construction of Public Roads in the Canton of Sarajevo for a period of 4 (four) years (2014 - 2018) (Ministry of Traffic Directorate for Roads of Sarajevo Canton, 2014). The following diagram shows the relationship between the main, regional and local roads in the Sarajevo Canton. 


\section{The relationship between the main, regional and local roads in the Sarajevo Canton.}

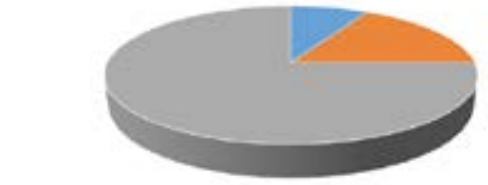

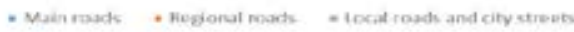

Fig. 1.

Participation of Main, Regional and Local Roads in the Sarajevo Canton Area

Number of registered motor vehicles in the Canton of Sarajevo area (BIHAMK, 2014; 2015 ; 2016) is presented below.

\section{Table 1}

Overview of Registered Vehicles in the Canton of Sarajevo

\begin{tabular}{|l|l|l|l|l|l|l|}
\hline Year & $\begin{array}{l}\text { Motor } \\
\text { vehicles }\end{array}$ & $\begin{array}{l}\text { Mopeds and } \\
\text { motorcycles }\end{array}$ & Buses & $\begin{array}{l}\text { Heavy } \\
\text { vehicles }\end{array}$ & Other & Total \\
\hline 2013 & 113,268 & 1,194 & 407 & 9,342 & 1,717 & 125,928 \\
\hline 2014 & 117,116 & 1,219 & 455 & 9,437 & 1,798 & 130,025 \\
\hline 2015 & 120,981 & 1,229 & 445 & 9,436 & 1,857 & 133,948 \\
\hline
\end{tabular}

By analyzing and comparing data on registered motor vehicles in Bosnia and Herzegovina in 2015 with data from the previous two years, despite the economic crisis, a slight increase in the number of registered motor vehicles $6.38 \%$ was noticed.
The fuel consumption data shown in Table 2 (Federal Hydrometeorological Institute, 2016) represents the data obtained on the basis of the calculation made by COPERT IV on the basis of other input data.

Table 2

Total Consumption of Certain Types of Fuel (in tons) in Sarajevo Canton in 2014

\begin{tabular}{|l|l|l|}
\hline \multicolumn{2}{|c|}{ Fuel type (tons) } \\
\hline Gasoline & Diesel & LPG \\
\hline 30,494 & 97,238 & 2,287 \\
\hline
\end{tabular}

With the aim of achieving as much specific engine power as possible, it strives to extract as much power for a specific engine's operating volume as possible with lower fuel consumption. The condition for this is engine construction with the highest compression ratio, which is achieved by the use of higher octane gasoline. To avoid detonating combustion, the tetracyclic antidetonator is added to gas, which, in the combustion process, does not pass but exits into the atmosphere with exhaust gases. More recently, unleaded petrol is increasingly used due to the adverse impacts of lead on 
the environment and the vehicle catalyst, and other means are used as antidetonation additives. With diesel engines, the presence of carbon monoxide in exhaust gases is far less than in gasoline engines (Table 3), but the more pronounced presence of solid matter (Federal Hydrometeorological Institute, 2016).

Table 3

Emission of Exhaust Gases Petrol and Diesel Engines

\begin{tabular}{|l|l|l|l|l|}
\hline Concentration kg/1001 & CO & CH & NO $_{\mathbf{x}}$ & Solid Matter \\
\hline OTO & 274 & 0.5 & 13.5 & 1.4 \\
\hline DISEL & 7.1 & 1.2 & 26.4 & 13.2 \\
\hline
\end{tabular}

Passenger cars, as sources of polluting substances, dominate in the case of concentrations of $\mathrm{CxHy}$ and $\mathrm{CO}$ as well as $\mathrm{CO}_{2}$ in the total emission of exhaust gas transport capacities, which is entirely understandable given the share of passenger cars in the total number of registered vehicles. However, heavy trucks and buses, although representing a small part of the world fleet (only 5\%), dominate as the main source of nitrous oxide ( $\mathrm{NOx}$ ).

The harmless exhaust fumes: Carbon dioxide $\left(\mathrm{CO}_{2}\right)$ is a colorless non-toxic gas, a product of combustion of carbon and organic compounds with a sufficient presence of oxygen followed by breathing, animals, plants and consumed by the processed (photosynthesis). By itself, it is not poisonous, but it provokes the green- house effect. This is the phenomenon of an increase in temperature of the earth due to the different permeability of the atmosphere to solar radiation. Earth warms up from the sun, whereby it reflects energy backwards. The consequence of increased gas concentration, especially $\mathrm{CO}_{2}$, does not allow the natural return of heat back into the atmosphere. $\mathrm{CO}_{2}$ passes short-wave solar radiation to the ground and does not penetrate the earth's long-range radiation into the atmosphere, so that heat is retained, thereby increasing the air temperature. There is no technology that would allow the elimination of $\mathrm{CO}_{2}$ from exhaust gases because combustion of fossil fuels (oil, natural gas, coal) creates $\mathrm{CO}_{2}$. The only way out is to reduce fuel consumption by developing a car with reduced fuel consumption and using alternative fuels.

\section{Table 4}

Values of Emitted Pollutants from Road Traffic in Canton Sarajevo in 2014

\begin{tabular}{|c|c|c|c|c|}
\hline \multirow{9}{*}{ 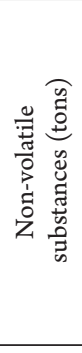 } & Substance & Value & Substance & Value \\
\hline & $\mathrm{CO}$ & 2067 & $\mathrm{PM}_{10} \mathrm{NE}$ & 49,49 \\
\hline & $\mathrm{CH}_{4}$ & 30 & $\mathrm{PM}_{10} \mathrm{U}$ & 205,63 \\
\hline & $\mathrm{NO}_{\mathrm{x}}$ & 1725 & $\mathrm{PM}_{2.5} \mathrm{E}$ & 135,52 \\
\hline & $\mathrm{NO}$ & 1373 & $\mathrm{PM}_{2,5} \mathrm{NE}$ & 26,70 \\
\hline & $\mathrm{NO}_{2}$ & 352 & $\mathrm{PM}_{2.5} \mathrm{U}$ & 162,22 \\
\hline & $\mathrm{N}_{2} 0$ & 12,8 & $\mathrm{OM}$ & 32,38 \\
\hline & $\mathrm{NH}_{3}$ & 18,6 & EC & 74,54 \\
\hline & $\mathrm{PM}_{10} \mathrm{E}$ & 156,14 & $\mathrm{SO}_{2}$ & 4,35 \\
\hline & $\mathrm{CO}_{2}$ & 408050 & & \\
\hline
\end{tabular}


Table 5

Values of Emitted Pollutants from Road Traffic in Canton Sarajevo in 2014

\begin{tabular}{|c|c|c|}
\hline \multirow{3}{*}{ 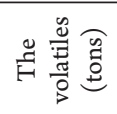 } & Substance & Value \\
\hline & VOC & 307 \\
\hline & NMVOC & 277 \\
\hline
\end{tabular}

Table 6

Values of Emitted Pollutants from Road Traffic in Canton Sarajevo in 2014

\begin{tabular}{|c|c|c|c|c|}
\hline \multirow{5}{*}{ 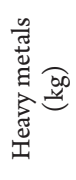 } & Substance & Value & Substance & Value \\
\hline & $\mathrm{Pb}$ & 70 & $\mathrm{Cu}$ & 324 \\
\hline & $\mathrm{Cd}$ & 1.5 & $\mathrm{Se}$ & 0.48 \\
\hline & $\mathrm{Ni}$ & 4.9 & $\mathrm{Zn}$ & 275 \\
\hline & $\mathrm{Cr}$ & 27 & & \\
\hline
\end{tabular}

\subsection{Measures to Reduce the Impact of Road Traffic on the Environmental Pollution in Canton Sarajevo}

Sarajevo Canton, or the city of Sarajevo, has characteristic natural geographic position that surrounded by mountain massifs without adequate flow of air which makes it possible to keep the gases in the valley where the city of Sarajevo is located. Also, what characterizes the city of Sarajevo and Sarajevo Canton is the high percentage of road vehicle fleet or motor vehicles which do not satisfy the norms of EU regulations which are defined after 1992. Road vehicles in Canton Sarajevo are characterized by high average age of the fleet as well as a significant share of road vehicles without a catalytic converter, with high proportion of the consumption of leaded gasoline in the total consumption of oil and petroleum products.

Due to the technological innovations of the cars, $\mathrm{CO}$ emissions have decreased even though the intensity of traffic has increased with respect to the emission since 1986 for $35 \%$. However, $\mathrm{NO}_{\mathrm{X}}$ emissions increased with respect to the emission since 1986 around $70 \%$ due to increased traffic intensity, regardless of the emission reduction. It can be expected that air pollution with $\mathrm{CO}$ in the level of roads will not exceed the limit values of pollution if they provide a fluent flow of traffic with the expected reduction coefficient (Federal Hydrometeorological Institute, 2016). However, a certain limitation on traffic intensity is the concentration of $\mathrm{NO}_{\mathrm{X}}$ that can be reduced only by reducing the emission coefficient, i.e., regenerating the fleet. Given the relatively high ground concentrations of NOx, the particular problem in this respect represents the formation of ground-level ozone $\left(\mathrm{O}_{3}\right)$, which is a very toxic gas.

There is expressed concern about energy potentials on earth, first for oil, which is the basic energy source for road vehicles caused exploring possibilities of using alternative fuels.

The things that should be emphasized in the environmental protection measures for Sarajevo Canton in this segment is the application of project from the aspect of the switch of road vehicles to natural gas.

The measures taken to reduce emissions of pollutants from motor vehicles may be listed as (Ministry of Traffic of Sarajevo Canton, 2005): 
- Application of new technicaltechnological solutions on motor vehicles (modern vehicle control systems, processing of exhaust gases, etc.);

- Regulatory and incentive measures to reduce emissions, as well as emission control technology;

- Improving fuel efficiency;

- Alternative fuels for the transport sector;

- Managing transport requirements.

The emission of harmful substances from exhaust gases from road motor vehicles can be solved by redirecting personal transport traffic to public city transport in the central city zone. In the city of Sarajevo there is a lack of an integrated system for continuous measurement of the basic air pollution indicators that should currently measure concentrations of air pollution Innovated design of integrated measuring stations is a version that allows the presentation of results on the display, so that citizens at any moment can be aware of the current air quality condition, and it is necessary to note that the presented data on a display represent only the current measured value.

Establishing a system of automatic measuring stations contributes to obtaining valid data, which can be used with the help of embedded computing components to create a high quality database, which is the basis for establishing a system in the region and connecting with other institutions. A very important issue is to compare the costs of protective measures in the environmental protection segment with the benefits of improving the overall ecological image and thus achieving optimum protection. Environmental damage caused by transport has not entered the financial construction of road construction costs, and exact data apart from financing, are also necessary for road infrastructure planning, which is why it is necessary to strive for an economically funded ecological policy.

\section{Model for Improvement of Ecological Parameters of the Traffic Control Center in the Sarajevo Canton}

High costs of construction of transport infrastructure, lack of space in urban areas, growing criteria on issues of preserving the quality of life and an acceptable level of service transport system, imposed the need for better utilization of the existing capacity of the network of roads. Great opportunities to address the complex demand that users and the society as a whole set in front of the traffic system are in the domain of traffic management.

Increasing mobility and the degree of motorization led to imbalances and conditions increasing the demand of network capacity, resulting in congestion on the network, which is now estimated to relate $2-4 \%$ of GDP per year in Europe. Notwithstanding the proclaimed policy and strategy, this will be the trend of the condition to avoid some unforeseen situation continue in the future. Central traffic management in Canton Sarajevo aims to efficiently solving of the process.

The objective of the present study is to develop speed dependent emission factors using On-board emission measuring instrument. The vehicle is run at different speed ranges for a long stretch of road with almost same gradient and less traffic. This test has been performed typically on three type of vehicles commonly used in India. Two wheelers could not be explored due 
to the limitation of the on-board machine sensors. This is an exploratory study and is first of its kind in India. In developing this model we have ignored variation in the distribution of vehicle type, age, make and are left as a scope for future investigations. Instead, three representative vehicles are considered. It may be noted that in this study the effect of acceleration/deceleration is considered only implicitly. The reason being several planning studies are done at macro level, which does not require the effect of acceleration/deceleration to be considered. For example, network design problems like capacity expansion problems, signal settings, optimal tolls etc. This study was done with the objective of further using the derived speed dependent emission factors for a network design problem.

\subsection{Central Traffic Management System}

The introduction of Traffic Management Center (TMC) would involve the application of new management, information, communication and sensor technologies into existing traffic and transport infrastructure in Sarajevo Canton and more importantly linking all these elements into one integral system. TMC is a system that provides information through a distributed and interconnected information system for use by whether within the private or public sector. The TMC system is customizable and open, offering, on the one hand, the application of various technologies of interactive and multimedia features, and, on the other hand, ensuring the integrity of activity across the area, from micro location, street to city and canton. The Traffic Management Center serves for traffic management in the urban area. In this way, the traffic signaling, the intersection, the road, the public transport of the city and the active traffic and traffic management are monitored from one location in order to reduce the congestion, as well as the coordination of traffic at times of special events, emergencies or daily stopand-go to traffic (Ministry of Traffic of Sarajevo Canton, 2017).

It is considered that traffic is the second air pollutant, after the emissions caused by heating systems in the Sarajevo Canton.

Emission sources vary by level, at local and regional level these are heating of dwellings and institutions, industry and traffic, while at national and global levels emissions come from strong sources (large industrial plants and thermal power plants) as well as emissions from surface sources (cities), or emission of individual states and continents.

The emission of pollutants from traffic is significant only at the local level. At this level of air pollution comes from out of pollutants and small combustion facilities. Adverse effects are expressed only in the area of emissions or next to that area. Due to the large number of vehicles, inadequate road network, inadequate vehicle maintenance, and poor quality inspection of emissions at technical examinations, the air is overly polluted by polluting materials of traffic origin, which is adversely affecting human health. The biggest effects on reducing air pollution from traffic are achieved by boosting public transport and reducing the use of personal vehicles. In addition to the use of public transport, it is evident that reducing fuel consumption in traffic also results in a significant reduction in air emissions. It is necessary to enable a faster flow of vehicles on the city's roads through adaptive traffic control. Reducing energy costs and environmental protection costs are important factors in deciding on 
building TMC, especially from the public sector standpoint. Important prerequisites are: increasing the number of passengers per vehicle, using public transport, aligning the traffic flow, managing demand for travel. The introduction of the TMC system will effectively increase the capacity of the road and thus eliminate the need for construction of new traffic facilities for high environmental costs. Considering the mentioned factors, it can be said that although there is a need for further development of the mentioned elements, it is not necessary to establish the center. However, bearing in mind that these elements are strongly interconnected and interdependent, and that different authorities in the Canton of Sarajevo are involved in their application and control and that there is no functional coordination between them, it is concluded that if it is necessary to develop the traffic system, taking into account all these elements, it is necessary to establish coordination that will be run on a daily and long-term, strategic level (Ministry of Traffic of Sarajevo Canton, 2017).

\subsection{Model for Reduction of Pollution - Introduction of Low-Emission Zone (LEZ)}

The Center for Traffic Management and Control includes the introduction of modern traffic signalization as a medium of communication with drivers (RDS-TMC), installation of traffic control devices and the environment, which enables the operational services to have an overview of the situation on the road, predict the occurrence of unfavorable situations, act properly and prevent possible traffic accidents, as well as traffic congestion at crossroads. Center management and traffic control, in addition to video surveillance of traffic, which was set up to monitor the individual security segments of traffic, it is necessary to monitor the environmental parameters of the observed sections.

The ecological parameters that need to be monitored are primarily the air quality, as well as the amount of noise caused by vehicles on the observed sections. Installation of measuring stations to follow parameters such as road temperature (it is very important for road patrol workers: whether at all and by what solution will be sprinkle road), visibility / fog on the road (important for traffic safety), wind speed, etc. The best way to track pollution is to install measuring stations on critical sections. There are already a number of measuring stations in the Canton of Sarajevo, however, the question is how to react to the pollution if excessive amounts of $\mathrm{CO}_{2} \mathrm{PM}_{10}$ and $\mathrm{SO}_{2}$ occur? Do we need to close that section? Do we need to eliminate older vehicles and if so, how?

The data from automatic measuring stations, which have recently been installed in Sarajevo show that exceeding pollutants exceed all allowable values, although new regulations and decisions provide definitions of limit values of certain pollutants in accordance with EU regulations, and the situation gets worse. Vehicle emissions are classified according to the so-called "Euro Standards". In many cases there is one more crucial factor, and that factor is whether the vehicle has a particle filter or a catalyst, or not.

One of the proposals to reduce pollution is to establish a Low Emission Zone (LEZ). This is a geographically defined area or certain roads where it is necessary to restrict or refuse access to vehicles which emit specific pollution or to allow the 
movement of vehicles with low-emission pollution such as hybrid vehicles or vehicles with zero emissions to improve air quality (Transport for London - Low Emission Zone, 2015).

This is often the most effective measure, which is set up to help cities reduce the problem of air pollution in their area. Low emission zones are introduced in areas where air pollution is at a level that is hazardous to the health of the population in order to improve air quality and to provide safer breathing.

By introducing the Low Emission Zone Criteria, the main objective is to exclude older cars that are more polluting, or to encourage operators to incorporate clean emission devices to meet the standard set of emissions. It also aims to accelerate earlier adoption of cleaner vehicles than would otherwise have occurred through the process of natural renewal of the fleet. However, as the fleet is constantly improving, emission reductions will be achieved by introducing the Low Emission Zone.

The most obvious way to set emission criteria for the Low Emission Zone is to use Euro Standards to limit the number of vehicles above a certain age corresponding to lower Euro standards.

Given its popularity in application, in European cities and beyond, the proposed model for reducing pollution has all the features of a good model: Feasibility, Relevance, Sustainability and Visibility.

In the Sarajevo Canton, the idea is to set up a low emission zone in the city center, from Marijin Dvor to Baščaršija (Figure 2), where it would not pay for low emission vehicles (Center for Economic, Technological and Environmental Development, 2015). LEZs would be issued on a daily, weekly and monthly base, and as soon as excessive pollution would occur, a ban would be introduced for non-LEZ vehicles.

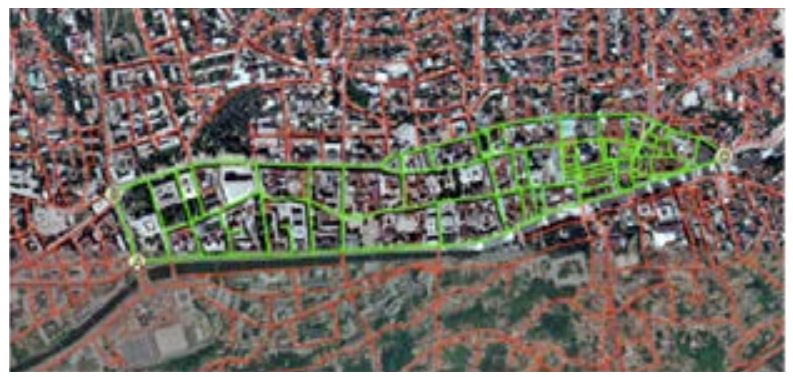

Fig. 2.

An Area Where will be Limited Movement of the Vehicles Which do not Meet the Prescribed Emission Standards

To drive in the Low emission zone without paying a daily fee, the vehicle must meet certain emission standards that limit the amount of particles coming from the exhaust systems of the vehicle. This is very easy to do if you have a Traffic Management Center.
Within the Low Emission Zone (LEZ) there are no barriers or toll ramps. Instead, the camera "reads" the registration number of the vehicle entering the Low emission zone and checks it in the Registered Vehicle database. 
This database should be compiled on the basis of the information about vehicle, driver, generic data, mass, mark and model of vehicles registered in the Canton of Sarajevo. It automatically tells whether the vehicle meets the emissions standards LEZ, whether the vehicle is free of charge, whether it has a discount or has already been paid for it. The low emission zone would operate 24 hours a day, 365 days per year.

In case the vehicle is not registered in Sarajevo Canton and goes through the LEZ, it is necessary at the entrance to Canton to entrap the vehicle into the database of the Traffic Management Center. This is essential for the following reason: if the vehicle moves to the LEZ without prior registration in the database, even if it meets the standards, it will have to pay a daily allowance or a punishment may be given to the home address. By reducing traffic pollution, the goal is to improve the health and quality of life of all citizens of Sarajevo. Figure 3 shows an Example of Signalization LEZ to Perform and That the Cameras are Covered, in Particular Sign or if Desired Tour LEZ (Urban Access Regulation in Europe, 2017).
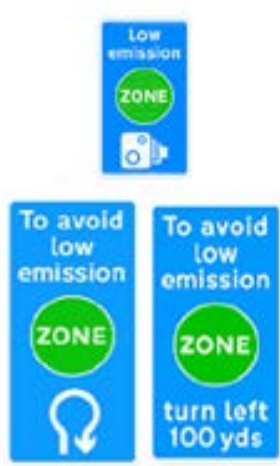

Fig. 3.

An Example of Signaling for LEZ

\subsubsection{Measures to Increase the Flow of Traffic in the Area of the Sarajevo Canton}

- Synchronizing the traffic control system (traffic lights and other light devices) Synchronized traffic control systems (traffic lights and other light devices) that keep traffic flow continuously, leading to the improvement of fuel efficiency of around $10 \%$. If these systems are equipped with indicators that advise drivers to extinguish their vehicles during standstill, especially in tunnels and bridges, then fuel savings are additionally increased, and consequently a reduction in the emission of harmful gases.

\section{- "SIGNALING HOPPER"}

Looking at the approach to a traffic zone, whether it comes to an open or closed traffic steered zone should be consistent speed group of vehicles that are approaching a crossroads. The reason for this is a direct impact on the number of stops the fuel consumption and the amount of exhaust gases. Speeds can be reconciled so that additional information on changing the signs 
warning drivers to set speed to at the next crossroads passed without stopping.

\section{- $\quad$ SPOT UTOPIA}

This model of controlled intersection began to apply in the 1980s in Italy with the aim of solving the problems of public urban transport. Due to its results, its application has grown significantly and has expanded both in Italy and throughout Europe to more than 30 European cities.

The basic principle of this system is to optimize the signal setting in real time in order to reduce the overall socio-economic cost of the traffic system in terms of avoiding congestion and emissions, and reducing travel times both for individual traffic and for priority vehicles.

UTOPIA has a hierarchical and distribution architecture consisting of a higher level (Center), which is responsible for setting the overall management strategy and the lower level (controlled intersections), where traffic control is performed using SPOT software.

Research has shown that this system reduced the travel time for individual vehicles by $15 \%$, for public transport vehicles up to $28 \%$, while the number of stops at the main arterial intersections decreased by $30 \%$.

- Installation of a system for securing the advantage of passing through public transport vehicles at intersections;

The right to pass by public transport vehicles by special traffic lanes, separated by a yellow full line with the established traffic signs and intensified punishment of drivers traveling by private vehicles by that traffic lane;

Proportionally this would increase traffic flow and reduce retention at intersections, which would also lead to a reduction in the concentration of exhaust gases.
- Establishment of certain restrictions on freight traffic in order to relieve internal city network

The ban on entering the city center (Pofalići - Baščaršija) of delivery and all other freight vehicles (over $3.5 \mathrm{t}$ ) in the period from 7.00 am to $8.00 \mathrm{pm}$.

- Installation of traffic signs with a supplemental traffic signs with increased punishment of the driver.

Such a measure would lead to a reduced frequency in traffic and, consequently, a smaller number of stops at semaforized intersections, that is, to a lesser concentration of exhaust gases.

Traffic Counting and measuring the amount of exhaust gases to major intersections shown to result implemented measures.

Direct and indirect benefits should be noted in the first five years. They relate to wider social benefits and are reflected in:

- reduction of time losses;

- $\quad$ savings due to lower number of holdings at intersections, ie due to lower fuel consumption;

- $\quad$ reduction of traffic accidents;

- $\quad$ prediction of crowding and conducting flows through alternative roads;

- detecting violators (it is only recognized that the registration number of vehicles passing through red);

- giving priority to public transport vehicles and savings this way has on the carrier's business.

Air quality in Sarajevo is a decade issue, and only the period in which it did not exist was war, when it did not work in the industry, nor was there any heating or car traffic. The meteorologists in Sarajevo are partly "blaming" the nature, which during 
the winter months due to the temperature inversion and the boiler position of the city creates the "lid" effect without the airflow underneath. Air quality in the years of war in Sarajevo is getting worse and returns to the situation as the late 60 s and 70 s, when the capital of Bosnia and Herzegovina was among the most polluted in the territory of the former Yugoslavia.

\section{Conclusion}

Sustainable mobility on the network of city roads cannot be achieved without reducing the adverse environmental impacts. Many cities have applied ITS systems to reduce air pollution especially in city centers. Air pollution is exacerbated by traffic congestion, so some ITS solutions improve the efficiency of traffic while reducing air pollution. Such specific services include: traffic flow management, air pollution monitoring, information on air quality, change of approach management approach to arteries with high levels of air pollution. In many situations environmental use can only be estimated by simulation.

The development and introduction of the CUS system can be considered one of the main steps that will stimulate the application of new information and communication technologies. The conditions of openness, interaction and flexibility of the system enhance the active role of economy and development, which necessarily monitors the construction, introduction and operation of the CUS subsystem.

At the beginning of the 21st century, traffic experts agreed that a successful solution to the growing problems of transport and transportation was no longer possible without the application of the ITS concept and technology (Intelligent Transport Systems). ITS is a management and information-communication superstructure of the classical traffic and transport system, by achieving significantly greater bandwidth, security, protection and ecological acceptance compared to solutions without ITS applications.

The basic task of traffic management is to utilize the capacitive capabilities of the available traffic network in a more rational and efficient way with the aim of providing a high level of service for the current traffic demand.

By establishing the Low-Emission Zone (LEZ) and through centralized traffic management in Sarajevo Canton, it will quickly and efficiently improve the pollution problem.

\section{References}

Center for Economic, Technological and Environmental Development. 2015. Available from internet: <www. ceteor.ba>.

Čaušević, S.; Bošnjak, I. 2011. System Engineering and Management (Sustavsko inženjerstvo i menadžment; In Bosnian). Faculty of Traffic and Communication, University of Sarajevo. Bosnia and Herzegovina. 19 p.

Federal Hydrometeorological Institute. 2016. Calculation of emission of pollutants from mobile sources - road traffic in FB\&H for 2014 (Proračun emisije zagađujućih tvari iz mobilnih izvora - cestovnog saobraćaja u Federaciji Bosne i Hercegovine za 2014. Godinu; In Bosnian). Sarajevo, Bosnia and Herzegovina. 76 p. (Unpublished study).

BIHAMK. 2014. Information on the total number of registered and sold new motor vehicles in $\mathrm{B} \& \mathrm{H}$ in the period January - December in 2013 (Informacija o 
ukupnom broju registrovanih i prodatih novih motornih vozila u BiH u periodu januar - decembar 2013; In Bosnian). Bosnia and Herzegovina. 10 p. Available from internet: <http://bihamk.ba/assets/files/JFlUMyffEWregistrovana-vozila-2013pdf.pdf $>$.

BIHAMK. 2015. Information on the total number of registered motor vehicles in $\mathrm{B} \& \mathrm{H}$ in the period January - December in 2014 (Informacija o registrovanim motornim vozilima u $\mathrm{BiH}$ u periodu januar - decembar 2014; In Bosnian). Bosnia and Herzegovina. 11 p. Available from internet: <http://bihamk.ba/assets/ files/5g9610xxIm-registrovana-vozila-14-newpdf.pdf $>$.

BIHAMK. 2016. Information on the total number of registered motor vehicles in $\mathrm{B} \& \mathrm{H}$ in the period January - December in 2015 (Informacija o registrovanim motornim vozilima u $\mathrm{BiH}$ u periodu januar - decembar 2015; In Bosnian). Bosnia and Herzegovina. 11 p. Available from internet: <http://bihamk.ba/assets/ files/UyGhHXc9gN-registrovana-vozila-15pdf.pdf>.

Lindov, O. 2013. Methodologies and Methods Environmental impact analysis (Metodologije i metode analiza uticaja transporta na okoliš; In Bosnian). Faculty of Traffic and Communication, University of Sarajevo, Bosnia and Herzegovina. 7 p.

Ministry of Traffic - Directorate for Roads of Sarajevo Canton. 2014. Mid-term Plan and Program for Maintenance, Protection, Reconstruction and Construction of Public Roads in the Canton of Sarajevo for a period of 4 (four) years (2014-2018) (Srednjoročni plan i program održavanja, zaštite, rekonstrukcije i izgradnje javnih puteva na području Kantona Sarajevo za period od 4 (četiri) godine (2014 - 2018); In Bosnian). Sarajevo. Bosnia and Herzegovina. 7 p.
Šimunović, Lj.; Bošnjak, I.; Božičević, S.; Pancirov, I. 2002. Impact of road traffic on air pollution (Utjecaj cestovnog prometa na onečišćenje zraka; In Croatian), Modern Traffic 22(5): 373-378.

Ministry of Traffic of Sarajevo Canton. 2017. Traffic analysis. Strategic directions for the development of traffic control center in Canton Sarajevo (Saobraćajni elaborat - Strateški pravci razvoja centra za upravljanje saobraćajem u Kantonu Sarajevo; In Bosnian). Sarajevo, Bosnia and Herzegovina, 28-59.

Ministry of Traffic of Sarajevo Canton. 2005. Traffic Study in Canton Sarajevo. Separat: Traffic Impact of the Sarajevo Canton (Studija saobraćaja na području Kantona Sarajevo, Separat: Uticaj saobraćaja na okolinu Kantona Sarajevo; In Bosnian). Sarajevo, Bosnia and Herzegovina.

Transport for London - Low Emission Zone. 2015. Available from internet: <www.tfl.gov.uk/roadusers/ lez/17678.aspx $>$.

Urban Access Regulation in Europe. 2017. Available from internet: <www.lowemissionzones.eu>. 